\title{
Nyelvtudásmérési és -értékelési műveltség: a magyarországi angoltanár (tovább)képzés aktuális kihívásai
}

\section{Csépes Ildikó}

\begin{abstract}
a Debreceni Egyetem Bölcsészettudományi Kar Angol Amerikai Intézet Angol Nyelvpedagógiai és Szakmódszertani Tanszékének egyetemi adjunktusa csepes.ildiko@arts.unideb.hu
\end{abstract}

\begin{abstract}
Tanulmányunkban arra vállalkozunk, hogy megvizsgáljuk egy 430 fós nem reprezentatív mintán magyarországi angoltanárok és tanárjelöltek nyelvtudásmérési és -értékelési müveltségét azzal összefüggésben, hogy mennyire érzik magukat magabiztosnak egyes mérési és értékelési területeken, illetve milyen (tovább)képzési igényeik vannak az egyes témakörökre vonatkozóan. Kutatásunk arra is kitér, hogy a válaszadók mely mérési és értékelési formákat használják a leggyakrabban az angolórákon. A vizsgált válaszadói mintára vonatkozó eredmények alapján megállapitható, hogy az órákon a hagyományos, eredményorientált nyelvtudásmérési és értékelési formák dominálnak. A tanulóközpontú, alternativ értékelési formák használata jóval kisebb arányú, és ezek iránt mutatkozik a legnagyobb (tovább)képzési igény. A válaszadók nyelvtudásmérési és -értékelési magabiztosságában eltérést találtunk egyes válaszadói csoportokra vonatkozóan, ami a képzési igényekhez, valamint a tanítási tapasztalathoz köthető. Végül ajánlásokat fogalmazunk meg a nyelvtanárképzésre vonatkozóan.
\end{abstract}

Kulcsszavak: nyelvtanárképzés, nyelvtudásmérési és -értékelési múveltség, tanulást támogató értékelés, pedagógiai értékelés

DOI: 10.37205/TEL-hun.2019.3-4.04

\section{Bevezetés}

A 21. század derekán indokoltnak tűnik a pedagógiai szemléletváltás, hogy megalapozhassuk az élethosszig tartó tanulás esélyét. Ehhez a tanításnak differenciálásra kell épülnie, és teljes eszköztárával azt kell támogatnia, hogy a tanuló önszabályozóvá váljon, és képes legyen magáért felelősséget vállalni (lásd OECD Future of Education and Skills 2030²). Einhorn (2015) véleménye szerint azonban a magyar közoktatás pedagógiai kultúrája viszonylag konzervatívnak tekinthető, hiszen a tanítási órákat tanárközpontú, ismeretalapú megközelítés jellemzi. Ez vo-

${ }^{2}$ https://www.oecd.org/education/2030-project/ 
natkozik az osztálytermi értékelésre is, mely alapjában véve „beskatulyáz és megbélyegez" (Einhorn, 2015, 54. o.), más szóval az értékelés alapja a másokkal történő összehasonlítás (normaorientált értékelés), és célja a minősítés (szummatív értékelés) ahelyett, hogy az értékelés a tanuló egyéni fejlődését célzottan támogatná. Az osztálytermi fejlesztő értékelés ez utóbbi formáját Black és Wiliam (1998) tanulást támogató értékelésnek (assessment for learning) nevezi. E szerint az osztálytermi folyamatokban kiemelt szerep jut a konstruktív visszacsatolásnak, a tanulói ön- és társértékelésnek, továbbá fontos, hogy a tanulók tisztában legyenek tanulási céljaikkal és az elérni kívánt normákkal. A differenciált osztálytermi értékelés katalizátorként növelheti a nyelvtanulás eredményességét, ezért az angoltanárok nyelvtudásmérési és értékelési műveltségének vizsgálata kiindulópont lehet a tanárképzők számára a vázolt szemléletváltás megvalósulásához.

Tanulmányunk célja annak feltárása, hogy magyarországi angoltanárok és tanárjelöltek egy nem reprezentatív, 430 főből álló mintája milyen nyelvtudásmérési és értékelési műveltséggel rendelkezik, és hogy a vizsgálatba bevont válaszadók milyen (tovább)képzési igénnyel rendelkeznek az osztálytermi értékelés területén. Jelen kutatásunk szorosan kapcsolódik egy nemzetközi projekthez, mely az Európai Unió támogatásával valósult meg Teachers' Assessment Literacy Enhancement ${ }^{3}$ (TALE) [Tanárok nyelvtudásmérési és értékelési műveltségének a fejlesztése] elnevezéssel.

\section{A nyelvtudásmérési és -értékelési múveltség fogalma}

Az 1970-es és 80-as években már körvonalazták, hogy a tanároknak általában véve milyen értékelési készségekkel és tudáselemekkel kell rendelkezniük (Schafer, 1991; Stiggins, 1991), de átfogó leírás csak az 1990-es években jelent meg. ${ }^{4}$ Egy 25 évvel későbbi tanulmány szerint (DeLuca és mtsai., 2016) ez a keretrendszer a mai napig meghatározó. Az eltelt időszakban a hangsúlyok változtak: a 90-es éveket a „tanárközpontúság” (a tanári értékeléshez szükséges kompetenciák definiálása) jellemezte, a 2000-es évek után megjelent a tanulói perspektíva - olyan fogalmaknak köszönhetően, mint a tanulást támogató értékelés (Black és Wiliam, 1998) és

\footnotetext{
${ }^{3}$ Erasmus+, Innovációt és bevált gyakorlatok megosztását célzó együttműködések, Stratégiai partnerség a közoktatásban, KA2 - http://taleproject.eu/

${ }^{4}$ Standards for Teacher Competence in Educational Assessment of Students [A tanári kompetencia követelményei a pedagógiai értékelésben, röviden Standards] (American Federation of Teachers, National Council on Measurement in Education és National Education Association, 1990)
} 
az értékelés mint tanulás (Earl és Katz, 2005) -, hogy a tanulókat is be lehessen vonni az értékelés folyamatába.

Az elmúlt két évtizedben a nyelvtudásméréssel foglalkozó szakemberek is egyre nagyobb figyelmet fordítottak az osztálytermi értékelés kutatására (ReaDickins, 2001; Davison és Leung, 2009; Hill és McNamara, 2012), és arra, hogy a nyelvtanároknak milyen elméleti és gyakorlati tudásra van szükségük az értékelés területén. Erre használják ma az Inbar-Lourie (2008) által bevezetett „nyelvtudásmérési és -értékelési műveltség” (language assessment literacy) kifejezést. Eszerint az nevezhető műveltnek a nyelvtudásmérés és -értékelés területén, aki „képes arra, hogy kritikus kérdéseket fogalmazzon meg, illetve meg is tudja válaszolni a feltett kérdéseket azzal kapcsolatban, hogy mi az értékelés célja, az alkalmazott mérési eszköz és a mérés körülményei megfelelőek-e, továbbá, hogy mi fog történni a mérés és értékelés eredményeképpen" (Inbar-Lourie, 2008, 389. o.; ford. a szerző). A fogalom értelmezése azóta is változik, és nincs egyetlen mindenki által elfogadott változat (Harding és Kremmel, 2016). Inbar-Lourie (2017) szerint a fogalom csiszolása során egyre szélesedő koncepcionális és gyakorlati repertoár irányába haladunk. Ebben az átmeneti időszakban a meghatározások magukban foglaltak tudás- és készségelemeket, alapelveket (például Brindley, 2001; Davies, 2008; Fulcher, 2012), megkülönböztetnek központi és hozzáadott komponenst (Brindley, 2001), és van, aki összekapcsolt tudáselemekről beszél (Inbar-Lourie, 2008; Xu és Brown, 2016). A nyelvtudásmérési és -értékelési műveltség alkotóelemeinek legmeghatározóbb összegzése Davies nevéhez köthető. Davies (2008, 328. o.) szerint a mérési és értékelési műveltség összetevői a következők:

- készségek (itemírás; tesztelemzés és statisztika alkalmazása; teszteléshez és tesztelemzéshez használható szoftverek ismerete),

- ismeretek (mérésszakmai, tesztelési ismeretek; a nyelvtudás nyelvészeti leírása; a tanítás és tanulás különböző modelljei),

- alapelvek (teszthatás; méltányosság; a tesztek megfelelő célú alkalmazása).

A Davies-féle definíció azonban döntően a mérési és értékelési szakemberekre vonatkozik. Pill és Harding (2013), valamint Taylor (2013) szerint a nyelvtudásmérési és -értékelési műveltség skálán jeleníthető meg, azaz relatív fogalom. A többdimenziós modellek különböző érdekcsoportokat különböztetnek meg, akiknek eltérő mélységű szakismeretre lehet szükségük, ami egy adott érdekcsoporton belül is jelentősen eltérhet környezeti vagy kontextuális tényezők miatt. Az érdek- 
csoportok közül a tanároknak van központi szerepük, így a kutatók is elsősorban ezt vizsgálták. Borg (2003) szerint például a nyelvtanárok szűkebb és tágabb értelemben vett környezeti befolyás miatt nem meggyőződéseik szerint tanítanak (és értékelnek). Ezek a hatások a tanárokkal szemben támasztott elvárások (a szülők, a kollégák, az iskola vezetése vagy a társadalom részéről), a rendelkezésre álló infrastruktúra és erőforrás is. Xu és Brown (2016) a kontextuális hatásokat három szintre szűkíti le: (1) nemzeti, (2) intézményi, (3) személyes szint. Yan és munkatársai (2018) szintén három szintet különítettek el, ezek: (1) a tágabb oktatási közeg és az oktatáspolitika, (2) az intézményi kötelezettségek és (3) a helyi intézményi kontextus. Ezeket a javasolt dimenziókat felhasználva, Vogt és munkatársai (2020) egy egyszerúbb elnevezésekkel ellátott, háromszintủ keretrendszert javasolnak: (1) makroszint (nemzeti/regionális szint), (2) mezoszint (intézményi szint) és (3) mikroszint (az osztályterem szintje), amelyek között komplex kölcsönhatások érvényesülnek. Fontos kiemelni tehát, hogy ugyan az osztálytermi értékelés „ágense” a tanár a saját képzési és tanítási tapasztalatával, de az értékelés módját a három kontextuális dimenzió hatásai együttesen alakítják.

A tanárképzés során nyert pedagógiai ismereteket hosszútávon felülírhatják a tanárok azon a meggyőződései, amelyek a tanítási tapasztalat során alakulnak ki értékelési döntéseikre vonatkozóan. Az is előfordul azonban, hogy a képzés hiányát pótolni képes a terepmunka során vagy tanárkollégáktól szerzett tapasztalat és gyakorlati tudás (Sheehan \& Munro, 2017). Xu és Brown (2016) értelmezése szerint a tanárok mérési és értékelési műveltsége dinamikus, összetett entitás, melyben összerendeződnek a tanárok értékelési ismeretei, készségei, meggyőződései, valamint a szúkebb és tágabb kontextusukban megtalálható korlátokra és lehetőségekre adott válaszaik. A fogalomnak új elnevezést is adtak: „tanári értékelési műveltség a gyakorlatban" (Teacher Assessment Literacy in Practice/ TALiP). Az alap- vagy továbbképzés során szerzett mérési és értékelési alapismeretek különböző szűrőkön mennek át: az egyén kognitív és érzelmi szűrőjén, majd a mikro- és a makrokörnyezet szürőjén (például osztály, munkaközösség, iskola, oktatási rendszer), végül a tanítási tapasztalat szűrőjén.

\section{A nyelvtudásmérési és -értékelési müveltségre vonatkozó empirikus kutatások}

Az Európában és azon kívül végzett felmérések alapján a nyelvtanárok mérési és értékelési műveltségét döntően a tanulás eredményorientált értékelése és a hagyományos tesztelési technikák használata határozza meg (Lewkowicz és Zawa- 
dowska-Kittel, 2010; Kvasova és Kavytska, 2014; Vogt és Tsagari, 2014; Hidri, 2015; Tsagari és Vogt, 2017; Seden és Svaricek, 2018; Sultana, 2019). Az elóbbi tendenciát alátámasztja az is, hogy a tanárképzés során nyújtott, a pedagógiai értékeléssel foglalkozó kurzusokon a tanulás eredményorientált értékelésén és nem a tanulást támogató értékelésen van a hangsúly (Kovácsné Duró, 2004; Volante \& Fazio, 2007; DeLuca és Klinger, 2010; Jin, 2010; Lam, 2015). Vígh és Kiss-Kovács (2019) összegzése szerint nemzetközi viszonylatban az állapítható meg, hogy az értékelési kurzusoknak kicsi a hatásuk a tanárjelöltek fejlődésére. Kovácsné Duró (2004) magyarországi vizsgálata, valamint DeLuca és Klinger (2010) Ontariobeli helyzetelemzése is ezt mutatja: a tanárjelöltek értékelési műveltségére a gyakorló tanítás során szerzett ismereteik és tapasztalataik hatnak leginkább. Ez utóbbiakra befolyással lehet az őket segítő mentor felkészültsége, mérési és értékelési műveltsége. Kovácsné Duró (2004) arra is rámutat, hogy az egyetemi képzés során tárgyalt változatos értékelési módszereket és eljárásokat a hallgatóknak nincs igazán lehetőségük „működés közben” megfigyelni vagy kipróbálni - még a tanítási gyakorlat alatt sem -, ezért az elmélet és a gyakorlat közötti szakadék fennmarad. A korábbról hozott diákélményeknek így meghatározó szerep jut: a tanárjelöltek értékelési műveltségét a már jól ismert, többnyire hagyományos értékelési módszerek határozzák meg. Sajnálatos módon a tanárképzési intézményekben nem mindenütt kötelező a pedagógiai értékeléssel kapcsolatos kurzus (vö. DeLuca és Klinger, 2010; Lam, 2015). Ez a megállapítás magyarországi viszonylatban is igaz az osztatlan angoltanár képzésben (1. táblázat).

Az önálló kurzus azért indokolt, mert a tanárjelölt a nyelvtudás osztálytermi értékeléséhez szükséges jártasságot nyelvspecifikusan tudja a leghatékonyabban elsajátítani, ráadásul az érvényben levő tanárképzési követelmények szerint az alternatív értékelési formák elsajátítása képzési előírás. ${ }^{5}$ A tanulás teszttechnikákra épülő eredményorientált, minősítő értékelése ki kell, hogy egészüljön a tanulást támogató értékeléssel (például tanulói ön- és társértékelés).

${ }^{5}$ (8/2013. (I. 30.) EMMI Rendelet: A tanári felkészítés közös követelményeiről és az egyes tanárszakok képzési és kimeneti követelményeiről, 2013) 
Pedagógusképzés • 18(46), 2019/3-4.

\begin{tabular}{|c|c|c|c|}
\hline Intézmény & $\begin{array}{c}\text { Van-e önálló } \\
\text { nyelvtudásmérési } \\
\text { kurzus?(igen/nem) }\end{array}$ & $\begin{array}{c}\text { Ha van önálló kurzus, } \\
\text { milyen formában? }\end{array}$ & $\begin{array}{c}\text { Kötelező } \\
\text { vagy } \\
\text { választható } \\
\text { a kurzus? }\end{array}$ \\
\hline Debreceni Egyetem & igen & szeminárium & kötelező \\
\hline $\begin{array}{l}\text { ELTE Savaria Egyetemi } \\
\text { Központ }\end{array}$ & igen & szeminárium & kötelező \\
\hline $\begin{array}{l}\text { Eötvös Loránd } \\
\text { Tudományegyetem }\end{array}$ & igen & előadás & kötelező \\
\hline Eszterházy Károly Egyetem & nem & - & - \\
\hline $\begin{array}{l}\text { Károli Gáspár Református } \\
\text { Egyetem }\end{array}$ & nem & - & - \\
\hline Miskolci Egyetem & nem & - & - \\
\hline Nyíregyházi Egyetem & igen & előadás+szeminárium & kötelező \\
\hline Pannon Egyetem & igen & szeminárium & kötelező \\
\hline $\begin{array}{l}\text { Pázmány Péter Katolikus } \\
\text { Egyetem }\end{array}$ & nem & - & - \\
\hline Pécsi Tudományegyetem & igen & szeminárium & kötelező \\
\hline Szegedi Tudományegyetem & igen & szeminárium & kötelező \\
\hline
\end{tabular}

\section{A kutatási kérdések}

Jelen tanulmányunkban a következő kutatási kérdésekre keressük a választ a magyarországi válaszadókra vonatkozóan:

1 Milyen mérési és értékelési területeken érzik magukat magabiztosnak a tanárok és a tanárjelöltek?

2 Milyen tesztelési és értékelési eljárásokat használnak a tanárok az angolórán?

3 Milyen továbbképzési igényeik vannak a tanároknak és a tanárjelölteknek a mérés és értékelés területén?

4 Van-e különbség a tanárok nyelvtudásmérési és -értékelési magabiztosságában tanítási tapasztalatuk függvényében?

5 Van-e különbség a tanárok között a képzési igények tekintetében annak függvényében, hogy mennyire magabiztosak a mérés és értékelés egyes területein? 


\section{A kutatás leírása}

Jelen kutatásunkhoz a TALE projekt keretei között létrejött felmérés kutatási eszközére támaszkodunk. A TALE kérdőív tartalmi kidolgozásakor figyelembe vettük a Standards for Teacher Competence in Educational Assessment of Students [A tanári kompetencia követelményei a pedagógiai értékelésben, röviden Standards] (American Federation of Teachers, National Council on Measurement in Education \& National Education Association, 1990) iránymutatásait. A tanári kompetencia követelményei (Standards) hét főbb területet jelölnek ki, melyeket a tanárképzési programoknak ajánlott a képzés során fejleszteniük. A pedagógiai értékelés elemei a következőek: a tanároknak képesnek kell lenniük, hogy

1. kiválasszák a megfelelő értékelési módszereket, melyek összhangban állnak tanítási célkitűzésekkel;

2. megtervezzék és létrehozzák a megfelelő értékelési módszereket;

3. akár külső, akár a saját maguk által kifejlesztett értékelési formát megfelelően alkalmazzák, és annak eredményét megfelelően értelmezzék a saját tanításukban;

4. az értékelés során kapott eredményeket fel tudják használni a diákok egyéni fejlődésének, a tanóra megtervezésének, a tanmenet kialakításának és az iskola jobbításának érdekében;

5. érvényes, teljesítményértékelésen alapuló osztályzási formát alakítsanak $\mathrm{ki}$;

6. az értékelés során kapott eredményeket megfelelően tudják közvetíteni a diákok, a szülők és más külső fél számára;

7. felismerjék az értékelés azon formáját vagy felhasználását, mely nem etikus, jogsértő vagy egyéb okoknál fogva helytelen.

A fenti területeken túl a tanári értékelési kompetencia vizsgálatához a TALE projekt kérdőívét további kérdésekkel is kibővítettük. Egyrészt a Joint Committee on Standards for Educational Evaluation [JCSEE] (Klinger és mtsai, 2015) útmutatásai alapján új területként megjelenítettük a tanulók bevonását az értékelésbe. Másrészt a Közös Európai Referenciakeret [KER] (2002) nyelvtudásmérésre vonatkozó egyes ajánlásait is figyelembe vettük a nyelvi készségek elkülönült és integrált mérésére, illetve a KER nyelvtudásszintjeire vonatkozóan. Az angol nyelvü kérdőív elérhető a TALE projekt honlapján (Needs analysis report), ${ }^{6}$ melynek

${ }^{6} \mathrm{https} / /$ taleproject.eu/pluginfile.php/2127/mod_page/content/2/TALE\%20Needs\%20analysis \%20report.pdf 
most csak jelen tanulmányunk szempontjából releváns részeit ismertetjük (a magyar nyelvű változatot lásd a Mellékletben). A kérdőív a következőkre tért ki:

- A válaszadók háttere: nem, életkor, tanítási tapasztalat, angoltanári végzettséget adó intézmény neve, korábbi képzés a nyelvtudásmérés és -értékelés területén.

- A jelenlegi osztálytermi gyakorlat feltérképezése az értékelésre vonatkozóan: milyen értékelési formákat és módszereket alkalmaznak, és milyen gyakran használják azokat (négyfokozatú Likert-skála).

- Mennyire magabiztosak a tanárok az idegennyelvi tesztelés és értékelés egyes területeinek alkalmazásában (négyfokozatú Likert-skála); mely területeken szeretnének továbbképzésben részt venni.

A tanári kérdőív központi része a válaszadók nyelvtudásmérési és -értékelési műveltségét vizsgálta: mely területek alkalmazásában magabiztosak, illetve mely területeken igénylik a (tovább)képzést. A kérdőívben 20 értékelési témakörről kellett nyilatkozniuk a válaszadóknak: magabiztosságukat négyfokozatú Likert-skálán kellett bejelölni. A kérdőív megbízhatósága megfelelőnek bizonyult (Cronbach-alfa $=0,931)$. Az adatfelvétel döntően online felületen - tanárjelöltek esetében papír alapon kitölthető formában - egy adott időintervallum (kb. 3 hónap) alatt történt 2016 tavaszán.

\section{Az adatközlők}

A TALE projekt nemzetközi adatbázisában 829 tanár és tanárjelölt szerepel, közülük 230 fő magyar adatközlő. Utóbbiak számát a további adatgyűjtés során kibővítettük 430 före, hogy hazai viszonylatban szélesebb válaszadói kört tudjunk bevonni a kutatási kérdések vizsgálatába. A kutatási mintánkban leendő ( $\mathrm{N}=168)$ és már gyakorló angoltanárok szerepeltek $(\mathrm{N}=262)$, akiket a képzési intézményükön keresztül értünk el egy-egy ott dolgozó oktató segítségével. A felkért közvetítők személyesen vették fel az adatokat a még képzésben lévő hallgatóktól, a korábban végzett hallgatókhoz pedig az adott intézmény tanulmányi rendszerén keresztül juttatták el az online kérdőív elérhetőségét. A válaszadás önkéntes volt. A válaszadók között a nemek tekintetében a nők vannak többségben (80,5\%), ami egybecseng Varga (2019) adataival, melyek szerint a gimnáziumokban 70\%-ban, a szakgimnáziumokban 65\%-ban nők tanítanak. A válaszadók több korosztályt is tanítanak, de döntően 13-18 év közöttieket. A tanítási tapasztalat alapján azonban igen széles spektrumot ölelnek fel az adatközlők (2. táblázat). 


\begin{tabular}{lc}
\hline Életkor & Magyar válaszadók\% $(\mathrm{N}=430)$ \\
\hline 25 év alatti & 28,1 \\
$26-35$ éves & 32,6 \\
$36-45$ éves & 25,8 \\
$46-55$ éves & 11,4 \\
56 év feletti & 2,1 \\
\hline Tanítási tapasztalat & \\
\hline 0 év (tanárjelölt) & 39,1 \\
1-5 év & 16,0 \\
6-10 év & 14,2 \\
11-15 év & 9,5 \\
15 évnél több & 21,2 \\
\hline 2. táblázat: A válaszadók korosztály és tanítási tapasztalat szerinti megoszlása
\end{tabular}

Mivel a válaszadók nyelvtudásmérési és -értékelési műveltsége összefüggésben állhat azzal, hogy kaptak-e ezen a területen képzést, megvizsgáltuk, hogy milyen arányban részesültek képzésben (a képzés jellegére nem vonatkozott kérdés). Összesen 171 fő nem részesült képzésben, ebből 99 fő gyakorló angoltanár, 72 fő tanárjelölt. Az előbbiek alapján megállapítható, hogy a képzésben nem részesült gyakorló angoltanárok az összes válaszadó gyakorló tanár (262 fö) 36,9\%-a, ami igen magas aránynak tünik.

A válaszadóknak nyilatkozniuk kellett arról, hogy melyik tanárképző intézményben tanulnak vagy szereztek korábban tanári diplomát. A 3. táblázatban látható, hogy az egyes intézményekhez tartozó válaszadók száma valószínűleg nem a valós képzési arányokat reprezentálja az adatbázisban. Ennek oka a kérdőíves adatgyűjtés korlátaiban és a válaszadási hajlandóságban keresendő. Legnagyobb arányban az Eötvös Loránd Tudományegyetem (17,0\%) és a Debreceni Egyetem $(15,8 \%)$ hallgatói és volt diákjai töltötték ki a kérdőívet. 
Pedagógusképzés • 18(46), 2019/3-4.

\begin{tabular}{lcc}
\hline Tanárképző intézmény & $\mathbf{N}(\mathbf{4 3 0})$ & $\mathbf{\%}$ \\
\hline DE (Debrecen) & 68 & 15,8 \\
ELTE (Budapest) & 73 & 17,0 \\
EKE (Eger) & 35 & 8,1 \\
KGRE (Budapest) & 43 & 10,0 \\
ME (Miskolc) & 54 & 12,6 \\
NYME (Szombathely) & 18 & 4,2 \\
PE (Veszprém) & 27 & 6,3 \\
PPKE (Budapest) & 18 & 4,2 \\
PTE (Pécs) & 27 & 6,3 \\
SZTE (Szeged) & 52 & 12,1 \\
\hline Egyéb & 15 & 3,5 \\
\hline
\end{tabular}

3. táblázat: A válaszadók tanárképző intézményenkénti eloszlása

\section{Eredmények és következtetések}

Tanárok és tanárjelöltek nyelvtudásmérési és -értékelési magabiztossága

A válaszadó tanárok és tanárjelöltek nyelvtudásmérési és -értékelési magabiztosságáról - a vizsgált értékelési/mérési témakörökre vonatkozóan - a 4. táblázat ad átfogó képet. 
Csépes Ildikó

\begin{tabular}{|c|c|c|c|c|}
\hline \multirow[t]{2}{*}{ Értékelési/mérési témakörök } & \multicolumn{2}{|c|}{$\begin{array}{l}\text { Tanárok } \\
(N=262)\end{array}$} & \multicolumn{2}{|c|}{$\begin{array}{c}\text { Tanárjelöltek } \\
(N=168)\end{array}$} \\
\hline & Átlag & Szórás & Átlag & $\begin{array}{c}\text { Szór } \\
\text { ás }\end{array}$ \\
\hline $\begin{array}{l}\text { 1. Az értékelés különböző céljainak } \\
\text { beazonosítása }\end{array}$ & 3,00 & ,652 & 2,63 &, 763 \\
\hline $\begin{array}{l}\text { 2. A megfelelő értékelési formák/technikák } \\
\text { kiválasztása }\end{array}$ & 3,11 & ,666 & 2,54 &, 773 \\
\hline $\begin{array}{l}\text { 3. Osztálytermi haladást mérő tesztek } \\
\text { összeállítása }\end{array}$ & 3,15 & ,736 & 2,40 & ,863 \\
\hline 4. Hallott szövegértés mérése & 2,93 &, 742 & 2,39 &, 789 \\
\hline 5. Beszédkészség értékelése & 3,07 & ,708 & 2,71 &, 822 \\
\hline 6. Olvasott szövegértés mérése & 3,16 & 674 & 2,74 &, 711 \\
\hline 7. Íráskészség értékelése & 3,03 & ,732 & 2,61 &, 811 \\
\hline 8. A négy nyelvi készség integrált mérése & 2,66 & ,784 & 2,33 &, 808 \\
\hline 9. Tanulói önértékelés használata & 2,40 &, 828 & 2,02 &, 851 \\
\hline 10. Tanulótárs általi értékelés használata & 2,16 &, 807 & 1,95 &, 821 \\
\hline 11. Tanulói portfólió használata & 1,67 & ,839 & 1,50 &, 742 \\
\hline $\begin{array}{l}\text { 12. Speciális tanulási nehézséggel rendelkező } \\
\text { tanulók értékelése (például diszlexia) }\end{array}$ & 1,85 &, 854 & 1,30 & ,615 \\
\hline $\begin{array}{l}\text { 13. A tanulók felkészítése külső vizsgákra } \\
\text { (például érettségi, nemzetközi nyelvvizsgák) }\end{array}$ & 3,08 & ,788 & 2,60 &, 849 \\
\hline $\begin{array}{l}\text { 14. Az értékelés szerepe egyéni tanulókra } \\
\text { vonatkozó döntések meghozatalában }\end{array}$ & 2,95 &, 736 & 2,53 &, 758 \\
\hline $\begin{array}{l}\text { 15. Az értékelés szerepe a tanított anyag } \\
\text { megtervezésében }\end{array}$ & 3,10 & ,682 & 2,70 &, 793 \\
\hline $\begin{array}{l}\text { 16. Annak felismerése, hogy a nyelvi } \\
\text { tesztelés/mérés hogyan befolyásolja a } \\
\text { tanítást }\end{array}$ & 2,87 & ,733 & 2,39 & ,854 \\
\hline $\begin{array}{l}\text { 17. A Közös Európai Referenciakeret (KER) } \\
\text { ismeretek alkalmazása a tanulók } \\
\text { értékeléséhez }\end{array}$ & 2,54 & 899, & 2,05 & ,947 \\
\hline $\begin{array}{l}\text { 18. Az értékelés eredményének értelmezése a } \\
\text { tanulók számára }\end{array}$ & 3,17 & ,704 & 2,89 & ,834 \\
\hline $\begin{array}{l}\text { 19. Az értékelés eredményének értelmezése } \\
\text { szülők és mások számára }\end{array}$ & 3,08 & ,738 & 2,69 & ,895 \\
\hline $\begin{array}{l}\text { 20. A nem megfelelő értékelési módszerek } \\
\text { felismerése }\end{array}$ & 2,74 & 754 & 2,35 &, 826 \\
\hline
\end{tabular}

4. táblázat: A tanárok és tanárjelöltek magabiztossági mutatói az egyes értékelési/mérési témakörökre vonatkozóan 
A 4. táblázatban látható, hogy bár a két válaszadói csoport magabiztossága minden vizsgált témakörben eltér (a tanárok magabiztosabbak), az mégis közös vonás, hogy a legkevésbé és a leginkább magabiztosnak azonos területeken érzik magukat: a legkevésbé magabiztosnak az alternatív, tanulóközpontú értékelési eljárásokban (9-12), a leginkább magabiztosnak pedig az olvasott szövegértés mérésében (6) és az értékelés eredményének tanulók számára történő értelmezésében (18).

A TALE projekt nemzetközi adatbázisa alapján fókomponens elemzést végeztünk a nyelvtudásmérési és kérdőíves válaszokban lefedett mérési és értékelési területekre vonatkozóan. A korrelációs mátrixban a korrelációk megléte a főkomponens feltételeként szolgál, és az erős korrelációk arra utaltak, hogy a változók alkalmasak a főkomponens elemzésre. Az anti-image kovariancia mátrix átlón kívüli elemei a változók szórásnégyzetének a többi változó által nem befolyásolt részét mutatják. Tekintettel arra, hogy ezek az értékek alacsonyak voltak, arra következtettünk, hogy a változók szórásnégyzetének kisebb része a többi változótól független. Az anti-image korrelációs mátrix fóátlójában lévő elemek értéke minden esetben 0,5 felett volt, így nem kellett kizárni a változók közül egyiket sem. A modell megfelelőségi próbájának értéke $0,94(\mathrm{KMO})$, ami igen erős faktorizációs lehetőséget jelent. Azt, hogy a változóink páronként nem korrelálatlanok-e, a Bartlett-teszttel vizsgáltuk $(\mathrm{p}<0,05)$. A kommunalitások értéke alapján hat változót kivettünk a faktor modellből, mivel értékük 0,5 alatt volt. Azt feltételeztük, hogy ezeknek a változóknak nincs elegendő erejük. A kapott eredmények alapján (5. táblázat) három fókomponens az összes főkomponens által képviselt szórásnégyzetnek együttesen több mint $64 \%$-át magyarázza, azaz a modell magyarázó ereje elfogadható. 
Csépes Ildikó

\begin{tabular}{lccc}
\hline Értékelési/mérési témakörök & \multicolumn{3}{c}{ Komponens } \\
\cline { 2 - 4 } & 1 & 2 & 3 \\
\hline Értékelési formák &, 704 & & \\
Hallott szöveg értése &, 754 & & \\
Beszédkészség &, 809 & & \\
Olvasott szöveg értése &, 776 & & \\
Íráskészség &, 633 &, 684 & \\
Integrált készségmérés & &, 745 & \\
\hline Egyéni tanulókra vonatkozó döntések & &, 632 &, 806 \\
Értékelés és tananyag tervezés & &, 789 &, 809 \\
Teszthatás & & &, 630 \\
Eredmények értelmezése a tanulók felé & & & \\
Eredmények értelmezése a szülők felé & & & \\
\hline Önértékelés & & & \\
Társértékelés & & & \\
Portfólió & & & \\
\hline
\end{tabular}

Kivonási módszer: Főkomponens elemzés

Rotációs módszer: Varimax Kaiser normalizációval

a. A rotációt 5 ismétléssel konvergáltuk.

5. táblázat: Forgatott Komponens Mátrixa (a nemzetközi adatbázis alapján)

Az első komponensnek „A tesztkészítés gyakorlata” elnevezést adtuk, mely magában foglalja a négy nyelvi készség elkülönült és integrált mérését. A második komponenshez - „A nyelvtudásmérés következményei” - sorolható minden olyan terület, amely az eredmények értelmezéséhez kapcsolható: a teszthatás, a tananyagtervezés, az egyes tanulókra vonatkozó döntések, valamint az eredmények értelmezése a tanulók és szülők számára. Végül a harmadik komponens: „Alternatív, tanulóközpontú értékelési eljárások”, a tanulótárs általi értékelést, a tanulói önértékelést és a tanulói portfóliót foglalják magukba. A megnevezett három komponens adja tehát az általunk vizsgált nyelvtudásmérési és -értékelési műveltség három, egymástól elkülönülő területét.

\section{Tesztelési és értékelési eljárások az angolórákon}

Második kutatási kérdésünk a válaszadó tanárok által használt tesztelési és értékelési eljárások gyakoriságát vizsgálta. A leíró statisztikát a 6. táblázat mutatja. A tanulás eredményorientált értékelése mindenütt dominál, a tanulást támogató értékelés formáit kevésbé gyakran alkalmazzák. A válaszadók által leggyakrabban használt értékelési módszer az aktív részvétel az órán, melyet a szóbeli beszámoló 
és a hosszabb írásbeli fogalmazás követ, míg a tanulói portfólió alkalmazására és a tanulótárs általi értékelésre lényegesen ritkábban kerül sor. Feltételezésünk szerint a tanulást támogató értékelési formák kevésbé gyakori alkalmazását magyarázhatja az, hogy a válaszadók kevésbé magabiztosak ezek használatában (lásd fentebb).

\begin{tabular}{lcc}
\hline \multirow{2}{*}{ Értékelési módszerek } & \multicolumn{2}{c}{$N=262$} \\
\cline { 2 - 3 } & Átlag & Szórás \\
\hline Szóbeli beszámoló & 2,81 & 0,92 \\
Teszt nyitott végú & 2,59 & 0,75 \\
válaszokkal & 1,39 & 0,65 \\
Tanulói portfólió* & 1,97 & 0,78 \\
Tanulótárs általi értékelés* & 3,33 & 0,64 \\
Teszt zárt végű válaszokkal & 2,21 & 0,74 \\
Tanulói önértékelés* & 2,72 & 0,79 \\
Hosszabb írásbeli fogalmazás & 3,16 & 0,79 \\
Aktív részvétel az órán & 2,19 & 0,83 \\
Fordítás &
\end{tabular}

6. táblázat: A tanárok osztálytermi értékelési módszereinek gyakorisági átlaga

\section{Képzési igények}

Harmadik kutatási kérdésünk a tanárjelöltek és tanárok mérési és értékelési (tovább)képzési igényeire irányult. A válaszadók képzési igényeinek részletes bontását a 7. táblázat mutatja.

A képzési igények tekintetében az állapítható meg, hogy egyetlen olyan javasolt képzési terület sincs, amelyre vonatkozóan ne lenne szükség tréningre. Értelemszerűen a tanárjelöltek igénye erőteljesebb, hiszen sokan közülük még nem részesültek tréningben (72 fö/42,8\%). Azonban mindkét válaszadói csoportban igen magas azoknak az aránya, akik igénylik a (tovább)képzést a tanulást támogató értékelési formákra vonatkozóan (tanulói portfólió: 58,9\% és 64,5\%; tanulótárs általi értékelés: $48,2 \%$ és 55\%; tanulói önértékelés: 51,2\% és 53,4\%). A tanárjelöltek és tanárok által leggyakrabban megjelölt képzési terület a speciális tanulási nehézséggel rendelkező tanulók értékelése (83,9\% és 67,2\%). Ez az eredmény azt jelzi, hogy a speciális tanulási nehézségekkel küzdő nyelvtanulók értékelése feltehetően nem kap elég figyelmet se az alapképzés, se a továbbképzés során. 


\begin{tabular}{|c|c|c|c|}
\hline \multirow{3}{*}{ Értékelési/mérési témakörök } & Tanárjelölt & Tanár & Összesen \\
\hline & $\%$ & $\%$ & $\%$ \\
\hline & $(N=168)$ & $(N=262)$ & $(N=430)$ \\
\hline 1. Az értékelés különböző céljainak beazonosítása & 33,9 & 29,8 & 31,9 \\
\hline 2. A megfelelő értékelési formák/technikák kiválasztása & 51,8 & 36,3 & 44,1 \\
\hline 3. Osztálytermi haladást mérő tesztek összeállítása & 50,0 & 31,7 & 40,9 \\
\hline 4. Hallott szövegértés mérése & 54,8 & 35,9 & 45,3 \\
\hline 5. Beszédkészség értékelése & 44,0 & 37,4 & 40,7 \\
\hline 6. Olvasott szövegértés mérése & 40,5 & 19,5 & 30,0 \\
\hline 7. Íráskészség értékelése & 38,7 & 30,2 & 34,5 \\
\hline 8. A négy nyelvi készség integrált mérése & 46,4 & 37,4 & 41,9 \\
\hline 9. Tanulói önértékelés használata & 51,2 & 53,4 & 52,3 \\
\hline 10. Tanulótárs általi értékelés használata & 48,2 & 55,0 & 51,6 \\
\hline 11. Tanulói portfólió használata & 58,9 & 64,5 & 61,7 \\
\hline $\begin{array}{l}\text { 12. Speciális tanulási nehézséggel rendelkező tanulók érté- } \\
\text { kelése (például diszlexia) }\end{array}$ & 83,9 & 67,2 & 75,6 \\
\hline $\begin{array}{l}\text { 13. A tanulók felkészítése külső vizsgákra (például érettsé- } \\
\text { gi, nemzetközi nyelvvizsgák) }\end{array}$ & 33,9 & 27,1 & 30,5 \\
\hline $\begin{array}{l}\text { 14. Az értékelés szerepe egyéni tanulókra vonatkozó dön- } \\
\text { tések meghozatalában }\end{array}$ & 30,4 & 21,8 & 26,1 \\
\hline 15. Az értékelés szerepe a tanított anyag megtervezésében & 28,6 & 20,2 & 24,4 \\
\hline $\begin{array}{l}\text { 16. Annak felismerése, hogy a nyelvi tesztelés/mérés ho- } \\
\text { gyan befolyásolja a tanítást }\end{array}$ & 32,1 & 26,0 & 29,1 \\
\hline $\begin{array}{l}\text { 17. A Közös Európai Referenciakeret (KER) ismeretek al- } \\
\text { kalmazása a tanulók értékeléséhez }\end{array}$ & 46,4 & 38,5 & 42,5 \\
\hline $\begin{array}{l}\text { 18. Az értékelés eredményének értelmezése a tanulók szá- } \\
\text { mára }\end{array}$ & 20,8 & 13,7 & 17,3 \\
\hline $\begin{array}{l}\text { 19. Az értékelés eredményének értelmezése szülők és má- } \\
\text { sok számára }\end{array}$ & 24,4 & 14,5 & 19,5 \\
\hline 20. A nem megfelelő értékelési módszerek felismerése & 45,8 & 42,0 & 43,9 \\
\hline Összes átlaga & 43,2 & 35,1 & 39,2 \\
\hline
\end{tabular}

7. táblázat: A válaszadó tanárjelöltek és tanárok (tovább)képzési igényei a megadott értékelési és mérési témakörökre vonatkozóan

\section{A nyelvtudásmérési és -értékelési magabiztosság és a tanítási tapasztalat összevetése}

Negyedik kutatási kérdésünk arra irányult, hogy van-e különbség a tanárok nyelvtudásmérési és -értékelési magabiztosságában tanítási tapasztalatuk függvényében. Feltételezésünk szerint a tanítási tapasztalat növekedésével a tanárok nyelvtudásmérési és -értékelési magabiztossága is erősödik, hiszen a tapasztala- 
tokból levont tanulságokat mindenki igyekszik a továbbfejlődéshez felhasználni. Ennek megfelelően hipotézisünk az volt, hogy a tapasztaltabb tanárok magabiztossága szignifikánsan különbözik a kevésbé tapasztalt tanárokétól. Először azt vizsgáltuk meg, hogy a válaszadó tanárok magabiztossága hogyan viszonyul egymáshoz a vizsgált három fókomponens függvényében. A leíró statisztikát a 8. táblázat mutatja.

\begin{tabular}{lccc}
\hline Nyelvtudásmérési és értékelési müveltség komponensei & $N$ & Átlag & Szórás \\
\hline 1. A tesztkészítés gyakorlata & 262 & 2,96 & 0,55 \\
2. A nyelvtudásmérés következményei & 262 & 3,03 & 0,54 \\
3. Alternatív, tanulóközpontú értékelési eljárások & 262 & 2,08 & 0,66 \\
\hline
\end{tabular}

8. táblázat: A tanárok magabiztossági átlagai fokkomponensenként

A 8. táblázatban látható eredmények azt mutatják, hogy a válaszadó tanárok a nyelvtudásmérés következményei tekintetében a legmagabiztosabbak, ezt követi a tesztkészítés gyakorlata, és az alternatív, tanulóközpontú értékelési eljárások használata terén tűnnek a legkevésbé magabiztosnak. Hipotézisünk szerint a válaszadó tanárok magabiztossága tanítási tapasztalatuk függvénye. Az angoltanárokat négy csoportba osztottuk tanítási éveik száma alapján. Az egyes csoportokra jellemző magabiztossági átlagokat a 9. táblázat tartalmazza.

\begin{tabular}{lcccc}
\hline $\begin{array}{l}\text { Nyelvtudásmérési és értékelési magabiztosság } \\
\text { (fókomponensenként) }\end{array}$ & Csoport & $N$ & $\begin{array}{c}\text { Átla } \\
g\end{array}$ & $\begin{array}{c}\text { Szór } \\
\text { ás }\end{array}$ \\
\hline & $1-5$ & 69 & 2,84 & 0,58 \\
1. A tesztkészítés gyakorlata & $6-10$ & 61 & 2,88 & 0,58 \\
& $10-15$ & 41 & 2,94 & 0,44 \\
& $15+$ & 91 & 3,13 & 0,51 \\
\hline & $1-5$ & 69 & 2,99 & 0,59 \\
2. A nyelvtudásmérés következményei & $6-10$ & 61 & 2,95 & 0,44 \\
& $10-15$ & 41 & 2,94 & 0,56 \\
& $15+$ & 91 & 3,16 & 0,55 \\
\hline & $1-5$ & 69 & 2,03 & 0,59 \\
eljárások & $6-10$ & 61 & 1,89 & 0,63 \\
& $10-15$ & 41 & 2,06 & 0,69 \\
\hline
\end{tabular}

9. táblázat: A tanárok magabiztossági átlaga (főkomponensenként) csoportonkénti bontásban

A feltételezett különbségek vizsgálatához Kruskal-Wallis próbát alkalmaztunk, mivel a vizsgált értékek nem normális eloszlásúak voltak. A kapott eredmények azt mutatták, hogy szignifikáns különbség van $(\mathrm{p}<0,05)$ a különböző csoportokhoz 
tartozó válaszadók magabiztossági átlagai között ( $\mathrm{p}=0,015$ [A tesztkészítés gyakorlata]; $\mathrm{p}=0,045$ [A nyelvtudásmérés következményei]; $\mathrm{p}=0,036$ [Alternatív, tanulóközpontú értékelési eljárások]. A legtapasztaltabb válaszadó tanárok összességében magabiztosabbnak tűnnek mindhárom főkomponens vonatkozásában, mint a náluk kevésbé tapasztalt tanárok. A kapott eredmény arra enged következtetni, hogy a többéves tanítási gyakorlat során szerzett tudás fokozza a tanárok magabiztosságát, ez az eredmény egybecseng Sheehan és Munro (2017) meglátásaival.

\section{A nyelvtudásmérési és -értékelési magabiztosság és a képzési igények összehasonlítása}

Ötödik kutatási kérdésünk arra irányult, hogy összefüggéseket tárjon fel a válaszadók egyes nyelvtudásmérési és -értékelési területeken jelzett magabiztossága és az adott terület iránti képzési igénye között. A válaszadók képzés iránti szükségletei a 7. táblázatban láthatók (lásd fentebb). Feltételezésünk az volt, hogy a válaszadók azokon a területeken szeretnének (tovább)képzésben részesülni, amelyeken a magabiztosságuk többnyire alacsony. Ide tartozik a speciális tanulási nehézséggel rendelkező tanulók értékelése, a tanulói portfólió használata, valamint a tanulói önértékelés és a tanulótárs általi értékelés használata.

Azt feltételeztük, hogy minél magabiztosabb valaki, annál kevésbé igényli a tréninget. Az általános magabiztosságot ezúttal a nyelvtudásmérési és -értékelési magabiztosság három fókomponensének átlaga adta, melyet korreláltunk a válaszadók tréning iránti általános igényével, amire külön mutatót hoztunk létre: összevontuk a nyelvtudásmérés 20 vizsgált részterületére kapott igények százalékos arányait. A Pearson-korreláció eredménye $-0,355(\mathrm{p}<0,001)$. Ez az eredmény megerősíti a feltételezésünket, hiszen a szignifikáns negatív korrelációs érték azt jelenti, hogy minél magabiztosabb valaki, annál kevésbé igényli a képzést az adott területre vonatkozóan.

\section{Ajánlások a nyelvtanárképzésre vonatkozóan}

A szakirodalmi áttekintés és a kapott eredmények fényében a továbbiakban ajánlásokat fogalmazunk meg arra irányulóan, hogy a nyelvtanárok alap- és továbbképzésében mely területen szükséges változtatás. Meggyőződésünk, hogy minden tanárjelölt számára elérhetővé kellene tenni a komplex szakirányú képzést a nyelvtudásmérésre és -értékelésre vonatkozóan. Ez abban az esetben valósítható 
meg, ha minden képző intézménynek önálló nyelvtudásmérési és -értékelési kurzusa van (Davies, 2008). A képzés csak úgy lehet sikeres, ha mind elméleti, mind gyakorlati ismereteket tartalmaz, és az elmélet és a gyakorlat közötti kapcsolódás lehetőségét megteremti azáltal, hogy a változatos értékelési módszereket és eljárásokat a hallgatók működés közben is megfigyelhetik vagy kipróbálhatják (vö. Kovácsné Duró, 2004). Meglátásunk szerint amíg a tanárképzés nem nyújt megfelelő teret ahhoz, hogy az egyén saját szintjén értelmezni tudjon egy pedagógiai eljárást, megismerje és megtapasztalja azt, valamint értékelje saját és tanártársai véleményének tükrében, addig az elmélet és a gyakorlat között tátongó szakadék felszámolásának kicsi az esélye.

Az alapképzésben biztosított kurzus során elengedhetetlen, hogy a hallgatók a minősítő értékelés mellett a fejlesztő értékelés célját és lehetséges formáit alaposabban megismerjék. Az általános pedagógiai értékelési kurzus mellett indokolt, hogy a tanárjelöltek a nyelvtudás osztálytermi értékeléséhez a jártasságot nyelvspecifikusan szerezzék meg a képzés során. Így a tanárjelöltek a saját szakjuknak megfelelő idegennyelvük kontextusában tudnák elsajátítani, hogyan lehet a tanári diagnosztikus visszacsatolást a nyelvtanulók egyéni jellemzőihez igazítani. Ezek közé sorolható például az életkor vagy a nyelvtudás szintje, melyek meghatározzák, hogy milyen nyelvi készségeket, lexikát és nyelvtani szerkezeteket ismerhet a tanuló. Az is fontos a tanárjelöltek számára, hogy megismerjék az alternatív értékelési formák (például a tanulói portfólió, az ön- és társértékelés, a tanári diagnosztikus célú visszacsatolás) lehetséges értékelési kritériumait, és fejleszthessék az azok alkalmazásához szükséges készségeket, mivel az értékelési kritériumok mind mennyiségi, mind minőségi vonatkozásban nagyban eltérhetnek a tanulók nyelvtudásának függvényében. Szükség van olyan útmutató kidolgozására, amely nyelvspecifikus leírást ad az alternatív értékelési formák osztálytermi használatához egy adott idegennyelv tanításában.

Az osztálytermi értékelésre vonatkozóan továbbképzési lehetőséget kell biztosítani a gyakorló tanárok számára, hogy nyelvtudásmérési és -értékelési műveltségük hiányosságait pótolni tudják. A továbbképzés biztosítása a mentor tanárok számára különösen indokolt, hogy a tanárjelöltek és az őket segítő mentor tanárok nyelvtudásmérési és -értékelési ismeretei adott esetben ne kerüljenek ellentmondásba. 


\section{Konklúzió}

Tanulmányunkban arra vállalkoztunk, hogy egy nem reprezentatív magyarországi minta alapján megvizsgáljuk az angoltanárok és tanárjelöltek nyelvtudásmérési és -értékelési mủveltségét annak alapján, hogy mennyire érzik magukat magabiztosnak egyes mérési és értékelési területeken, illetve milyen (tovább)képzési igényeik vannak az egyes témakörökre vonatkozóan. A kutatás arra is kitért, hogy feltérképezze az angolórákon használt mérési és értékelési formákat, azok előfordulási gyakoriságát. Az összkép azt jelzi, hogy az órákon a hagyományos, eredmény-orientált nyelvtudásmérési és értékelési formák dominálnak. Az alternatív értékelési formák használata ritkább, és azok közül is a tanulói portfólió használata a legkevésbé gyakori. Ez az eredmény megerősíti Einhorn (2015) feltételezését, mely szerint a nyelvórákon a normaorientált, minősítő értékelés meghatározó jelentőséggel bír, a tanulást támogató értékelés pedig háttérbe szorul.

A válaszadó tanárok nyelvtudásmérési és -értékelési magabiztossága összefüggést mutat tanítási tapasztalatukkal, azaz a tanítási gyakorlat során szerzett tudás fokozhatja a tanárok magabiztosságát. Azonban azok a területek, melyeken a tanárjelöltek és a tanárok a leginkább, illetve a legkevésbé magabiztosak, megegyeznek. A válaszadók kevésbé magabiztosak a speciális tanulási nehézséggel rendelkező tanulók értékelése, a tanulói portfólió, valamint a tanulói önértékelés és a tanulótárs általi értékelés területén. A képzés iránti igények pedig ezzel szoros összefüggést mutatnak, hiszen a visszajelzések alapján a legnagyobb igény egységesen az előbbiek iránt mutatkozik. Egyetlen olyan javasolt képzési területet sem találtunk, amelyre vonatkozóan ne lenne szükség tréningre. Megerősítést nyert továbbá az a feltételezésünk, mely szerint minél magabiztosabb valaki, annál kevésbé igényli a képzést az adott területre vonatkozóan.

A kutatás korlátai között fontos megemlíteni, hogy az egyes tanárképző intézményekhez kapcsolt válaszadók száma nem a valós képzési arányokat reprezentálja, ezért kapott eredményeink nem általánosíthatóak. A válaszadók állításai önbevalláson alapulnak, így valóságtartamukat nem lehet ellenőrizni. Az előbbi korlát miatt következtetéseink érvényessége gyengülhet. A kutatási kérdések vizsgálatának további lehetséges irányai közé soroljuk az osztálytermi értékelési módszerek részletesebb vizsgálatát (például tanárok és tanárjelöltek által készített nyelvi tesztek elemzésével vagy tanórai megfigyeléssel). Az utóbbi esetben javasoljuk, hogy a megfigyelési szempontok kitérjenek a tanulást támogató értékelés megvalósítására is. 
A bevezetőben említett pedagógiai értékelési kultúra megváltoztatásának szükségességét kutatási eredményeink is alátámasztják. Feltételezésünk szerint a szemléletváltásához a tanárképzés területén kell az első lépéseket megtenni. Elengedhetetlen, hogy a (tovább)képzési lehetőségek megfelelő számban és minőségben rendelkezésre álljanak a magyarországi tanárképző intézményekben, és a képzések nyomán a nyelvtanárok mérésszakmai felkészültsége és meggyőződései jobban igazodhassanak a modern pedagógiai értékelési elvekhez.

\section{Köszönetnyilvánítás}

Jelen tanulmányunkban felhasználtuk a nemzetközi TALE projekt (Erasmus+ stratégiai partnerség, projekt száma: 2015-1-CY1-KA201-011 863) 2016-ban létrehozott adatbázisának egy részét, így köszönettel tartozunk a projektben résztvevő kollégáknak, akikkel a kutatást közösen megterveztük és lebonyolítottuk: Dr. Dina Tsagari (University of Cyprus, Ciprus); Prof. Karin Vogt és Veronika Froehlich (University of Education Heidelberg, Németország); Prof. Anthony Green és Prof. Liz Hamp-Lyons (University of Bedfordshire, Nagy-Britannia); Dr. Nicos C. Sifakis és Stefania Kordia (Hellenic Open University, Görögország); Fekete Adrienn (Debreceni Egyetem).

\section{Irodalom}

A Nemzeti alaptanterv kiadásáról, bevezetéséről és alkalmazásáról 110/2012. (VI. 4.) Korm. rendelet. (2012): Magyar Közlöny, 66, 10 635-10 848. https://ofi.oh.gov.$\mathrm{hu} /$ sites/default/files/attachments/mk_nat_20 121.pdf (Letöltés: 2019.09.29.)

American Federation of Teachers, National Council on Measurement in Education \& National Education Association (1990): Standards for Teacher Competence in Educational Assessment of Students. Educational Measurement: Issues and Practice, 9. évf., 4. sz. 30-32. https://doi.org/10.1111/j.1745-3992.1990.tb00391.x

Black, P. - Wiliam, D. (1998): Inside the black box: Raising standards through classroom assessment, Phi Delta Kappan International. http://edci770.pbworks.com/w/file/fetch/48 124 468/BlackWiliam_1998.pdf (Letöltés: 2019.12.27.)

Borg, S. (2003): Teacher cognition in language teaching: A review of research on what language teachers think, know, believe and do. Language Teaching, 36. évf., 2. sz. 81-109. https://doi.org/10.1017/S0 261444803001903

Brindley, G. (2001): Language assessment and professional development. In: C. Elder, A. Brown, K. Hill, N. Iwashita, T. Lumley, T. McNamara és K. O’Loughlin 
(szerk.): Experimenting with uncertainty: Essays in honour of Alan Davies. Cambridge University Press, Cambridge, 126-136.

Davies, A. (2008): Textbook trends in teaching language testing. Language Testing, 25. évf., 3. sz. 327-347. https://doi.org/10.1177/0 265532208090156

Davison, C., - Leung, C. (2009): Current Issues in English Language Teacher-Based Assessment. TESOL Quarterly, 43. évf., 3. sz. 393 415. https://doi.org/ 10.1002/j.1545-7249.2009.tb00 242.x

DeLuca, C. - Klinger, A. (2010): Assessment literacy development: identifying gaps in teacher candidates' learning. Assessment in Education: Principles, Policy \& Practice, 17. évf., 4. sz. 419-438.

https://doi.org/10.1080/0 969594X.2010.516643

DeLuca, C. - LaPointe-McEwan, D. - Luhanga, U. (2016): Teacher assessment literacy: a review of international standards and measures. Educational Assessment, Evaluation and Accountability, 28. évf., 3. sz. 251-272.

https://doi.org/10.1007/s11 092-015-9233-6

Earl, L. - Katz, S. (2005): Rethinking classroom assessment with purpose in mind. Winnipeg, Manitoba: Western Northern Canadian Protocol. https://digitalcollection.gov.mb.ca/awweb/pdfopener? smd $=1 \&$ did=12 503\&md=1 (Letöltés: 2019.11 .30 .)

Einhorn, Á. (2015): Pedagógiai kultúraváltás az idegennyelv-tanításban? Vitaindító. Modern Nyelvoktatás, 21. évf., 4. sz. 48-58.

Harding, L. - Kremmel, B. (2016): Teacher assessment literacy and professional development. In D. Tsagari \& J. Banerjee (szerk.): Handbook of second language assessment. Mouton De Gruyter, Amsterdam. 413-428.

Hidri, S. (2015): Conceptions of assessment: investigating what assessment means to secondary and university teachers. Arab fournal of Applied Linguistics, 1. évf., 1. sz. 19-43. https://files.eric.ed.gov/fulltext/EJ1 207 924.pdf (Letöltés: 2019.10.03.)

Hill, K. - McNamara, T. (2012): Developing a comprehensive, empirically based research framework for classroom-based assessment. Language Testing, 29. évf., 3. sz. 395-420. https://doi.org/10.1177/0 265532211428317

Inbar-Lourie, O. (2008): Constructing a language assessment knowledge base: A focus on language assessment courses. Language Testing, 25. évf., 3. sz. 385402. https://doi.org/10.1177/0265 532208090158

Jin, Y. (2010): The place of language testing and assessment in the professional preparation of foreign language teachers in China. Language Testing, 27. évf., 4. sz. 555-584. https://doi.org/10.1177/0265532 209351431 
Klinger, D. A. - McDivitt, P. R. - Howard, B. B. - Munoz, M. A. - Rogers, W. T. Wylie, E. C. (2015): The classroom assessment standards for PreK-12 teachers. Kindle Direct Press.

Kovácsné Duró, A. (2004): Tanár szakos egyetemi hallgatók értékelési tudása és kompetenciái. Magyar Pedagógia, 104. évf., 2. sz. 203-224. http://av.edia.hu/ mped/document/Kovacsne\%20Duro_MP1042.pdf (Letöltés: 2019.01.15.)

Közös Európai Referenciakeret. Nyelvtanulás, nyelvtanítás, értékelés. (2002): Pedagógustovábbképzési Módszertani és Információs Központ Kht., Budapest.

Kvasova, O. - Kavytska, T. (2014): The assessment competence of university foreign language teachers: A Ukrainian perspective. CercleS, 4. évf., 1. sz. 159-177. http://ualta.in.ua/wp-content/uploads/2016/04/Kvasova-Kavytska_2014_en.pdf (letöltés: 2019.04.10.)

Lam, R. (2015): Language assessment training in Hong Kong: Implications for language assessment literacy. Language Testing, 32. évf. 2. sz. 169-197. https://doi.org/10.1177/0265532214554321

Lewkowicz, J. - Zawadowska-Kittel, E. (2011): Classroom-based Assessment: the Polish Experience. In D. Tsagari \& I. Csépes (szerk.): Classroom-Based Language Assessment. Peter Lang GmbH, Frankfurt am Main, 147-167.

Pill, J., \& Harding, L. (2013): Defining the language assessment literacy gap: Evidence from a parliamentary inquiry. Language Testing, 30. évf., 3. sz. 381-402. https://doi.org/10.1177/0265532213480337

Rea-Dickins, P. (2001): Mirror, mirror on the wall: Identifying processes of classroom assessment. Language Testing, 18. évf., 4. sz. 429-462. https://doi.org/ 10.1177/026553220101800407

Schafer, W. D. (1991): Essential Assessment Skills in Professional Education of Teachers. Educational Measurement: Issues and Practice, 10. évf., 1. sz. 36. https://doi.org/10.1111/j.1745-3992.1991.tb00 170.x

Seden, K. - Svaricek, R. (2018): Teacher Subjectivity Regarding Assessment: Exploring English as a Foreign Language Teachers' Conceptions of Assessment Theories that Influence Student Learning. CEPS fournal, 8. évf., 3. sz. 119-139. https://doi.org/10.26529/cepsj.500

Sheehan, S. - Munro, S. (2017): Assessment: Attitudes, practices and needs. ELT Research Papers, 17.08. UK: British Council, London. https://www.teachingenglish.org.uk/sites/teacheng/files/pub_G239_ELTRA_Sheenan\%20and \%20Munro_FINAL_web\%20v2.pdf (Letöltés: 2019.11.01.)

Stiggins, R. J. (1991): Relevant Classroom Assessment Training for Teachers. Educational Measurement: Issues and Practice, 10. évf., 1. sz. 712. https://doi.org/ 10.1111/j.1745-3992.1991.tb00 171.x 
Sultanana, N. (2019): Language assessment literacy: an uncharted area for the English language teachers in Bangladesh. Language Testing in Asia, 9. évf., 1. sz. 1-14. https://doi.org/10.1186/s40 468-019-0077-8

Taylor, L. (2009): Developing Assessment Literacy. Annual Review of Applied Linguistics, 29, 21-36. https://doi.org/10.1017/S0 267190509090035

Tsagari, D. - Vogt, K. (2017): Assessment Literacy of Foreign Language Teachers around Europe: Research, Challenges and Future Prospects. Papers in Language Testing and Assessment, 6. évf., 1. sz. 41-63. https://www.researchgate.net/profile/Dina_Tsagari2/publication/316 981583_Assessment_Literacy_of_Fo reign_Language_Teachers_around_Europe_Research_Challenges_and_Future Prospects/links/591b753f0f7e9b7727d8a84a/Assessment-Literacy-of-ForeignLanguage-Teachers-around-Europe-Research-Challenges-and-Future-Prospects.pdf (Letöltés: 2019.10.25.)

Vígh T. - Kiss-Kovács R. (2019): Hogyan értelmezik a tanárszakosok a tanulói értékelés fogalmát? Modern Nyelvoktatás, 25. évf., 3-4. sz. 156-173.

Vogt, K. - Tsagari, D. (2014): Assessment Literacy of Foreign Language Teachers: Findings of a European Study. Language Assessment Quarterly, 11. évf., 4. sz. 374-402. https://doi.org/10.1080/15 434303.2014.960046

Vogt, K. - Tsagari, D. - Spanoudis, G. (2020): What Do Teachers Think They Want? A Comparative Study of In-Service Language Teachers' Beliefs on LAL Training Needs. Language Assessment Quarterly, 17. évf., 4. sz. 386409. https://doi.org/10.1080/15 434303.2020.1781128

Volante, L. - Fazio, X. (2007): Exploring teacher candidates' assessment literacy: Implications for teacher education reform and professional development. $\mathrm{Ca}$ nadian Fournal of Education, 30. évf., 3. sz. 749-770. https://journals.sfu.ca/cje/ index.php/cje-rce/article/view/2973/2262 (Letöltés: 2019.09.23.)

Xu, Y. - Brown, G. T. L. (2016): Teacher assessment literacy in practice: A reconceptualization. Teaching and Teacher Education, 58. évf., 149-162. https://doi.org/10.1016/j.tate.2016.05.010

Yan, X. - Zhang, C. - Fan, J. J. (2018): "Assessment knowledge is important, but ... ": How contextual and experiential factors mediate assessment practice and training needs of language teachers. System, 74., 158-168. https://doi.org/ 10.1016/j.system.2018.03.003 


\section{Language Assessment Literacy: Issues and Challenges in English Teacher Education in Hungary}

The study is aimed at exploring English language teachers' and teacher trainees' language assessment literacy (LAL) in the Hungarian context using a non-representative sample of 430 respondents. We examined their level of confidence in various classroom-based assessment areas and identified their training needs. The study also provides insights into which assessment methods are used most frequently in English lessons. The findings reveal that classroom-based assessment can be characterised by an overwhelming presence of traditional, teacher-centred forms of assessment with emphasis on assessment of learning. Less attention is given by respondents to alternative forms that support learning (assessment for learning), and respondents' training needs appear to be the strongest especially in these areas. There are differences in the pre- and in-service teachers' LAL confidence that can be linked to their teaching experience and training needs. Finally, in the light of the research findings we make some recommendations for teacher education in Hungary.

Keywords: teacher training, language assessment literacy, assessment for learning, classroom-based assessment 


\section{Mellékletek}

A TALE projekt angol nyelvủ kérdőívének a tanulmányra vonatkozó releváns részei:

\section{I. Általános információ}

1. Nem:

$\begin{array}{ll}\text { 1. } \square \text { férfi } & \text { 2. } \square \text { nő }\end{array}$

2. Kor:
1. $\square 25$ év alatti
2. $\square$ 26-35
3. $\square 36-45$
4. $\square 46-55$
5. $\square 56+$

3. Tanítási tapasztalat (évek száma):
1. $\square$ tanárjelölt
2. $\square 1-5$
3. $\square 6-10$
4. $\square 10-15$
5. $\square 15+$

4. Melyik főiskolán/egyetemen tanult/tanul?
1. $\square$ ELTE
2. $\square$ PTE
3. $\square$ SZTE
4. $\square$ PPKE
5. $\square$ KGRE
6. $\square \mathrm{DE}$
7. $\square \mathrm{ME}$
8. $\square \mathrm{PE}$
9. $\square$ NYME
10. $\square \mathrm{EKE}$

11. $\square$ egyéb:

5. Milyen idegen nyelvet tanít/fog tanítani?
1. $\square$ angol
2. $\square$ francia
3. $\square$ német
4. $\square$ spanyol

5. $\square$ egyéb:

6. Mi a legmagasabb végzettsége?

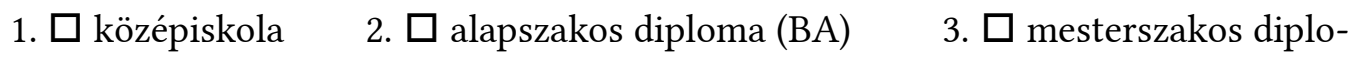
ma (MA) 4. $\square$ egyéb:

7. Milyen korú diákokat tanít? (többet is bejelölhet)
1. $\square$ 6-12
2. $\square$ 13-15
3. $\square 16-18$
4. $\square$ over 18

8. Részesült-e képzésben a nyelvtudásmérés és értékelésre vonatkozóan?
1. $\square$ igen
2. $\square$ nem

\section{A mérés és értékelés gyakorlata}

9. Milyen gyakran alkalmazza az alábbi mérési és értékelési formákat, hogy a tanulók angol nyelvi tudását értékelje? 
Pedagógusképzés • 18(46), 2019/3-4.

\begin{tabular}{l|l|l|l|l} 
& $\begin{array}{c}\text { nagyon } \\
\text { gyakran }\end{array}$ & gyakran & néha & soha \\
\hline 1. Szóbeli beszámoló & & & & \\
\hline $\begin{array}{l}\text { 2. Teszt nyitott végű } \\
\text { válaszokkal }\end{array}$ & & & & \\
\hline 3. Tanulói portfólió & & & & \\
\hline 4. Tanulótárs általi értékelés & & & & \\
\hline $\begin{array}{l}\text { 5. Teszt zárt végú válaszokkal } \\
\text { (pl. feleletválasztós teszt, } \\
\text { párosítás) }\end{array}$ & & & & \\
\hline 6. Tanulói önértékelés & & & & \\
\hline $\begin{array}{l}\text { 7. Hosszabb írásbeli fogalmazás } \\
\text { (pl. levél, esszé) }\end{array}$ & & & & \\
\hline 8. Aktív részvétel az órán & & & & \\
\hline 9. Fordítás & & & & \\
\hline 10. Egyéb & & & & \\
\hline
\end{tabular}

\section{III. Értékelési profil és képzési igény}

10. ELŐSZÖR jelölje be, hogy mennyire érzi magát magabiztosnak a felsorolt területeken.

11. AZUTÁN jelölje be a jobbszélső oszlopban, hogy mely területeken szeretne képzésen részt venni. 
11. kérdés

12. kérdés

\begin{tabular}{|c|c|c|c|c|c|}
\hline & $\begin{array}{l}\text { igen ma- } \\
\text { gabiztos- } \\
\text { nak érzem } \\
\text { magam }\end{array}$ & $\begin{array}{l}\text { magabiz- } \\
\text { tosnak ér- } \\
\text { zem ma- } \\
\text { gam }\end{array}$ & $\begin{array}{l}\text { kevéssé } \\
\text { érzem } \\
\text { magam } \\
\text { magabiz- } \\
\text { tosnak }\end{array}$ & $\begin{array}{l}\text { egyáltalán } \\
\text { nem va- } \\
\text { gyok ma- } \\
\text { gabiztos }\end{array}$ & $\begin{array}{c}\text { Szeretnék } \\
\text { képzésben } \\
\text { részesülni } \\
()\end{array}$ \\
\hline $\begin{array}{l}\text { 1. Az értékelés kü- } \\
\text { lönböző céljai- } \\
\text { nak beazonosítá- } \\
\text { sa }\end{array}$ & & & & & \\
\hline $\begin{array}{l}\text { 2. A megfelelő ér- } \\
\text { tékelési formák/ } \\
\text { technikák kivá- } \\
\text { lasztása } \\
\end{array}$ & & & & & \\
\hline $\begin{array}{l}\text { 3. Osztálytermi ha- } \\
\text { ladást mérő tesz- } \\
\text { tek összeállítása }\end{array}$ & & & & & \\
\hline $\begin{array}{l}\text { 4. Hallott szövegér- } \\
\text { tés mérése }\end{array}$ & & & & & \\
\hline $\begin{array}{l}\text { 5. Beszédkészség } \\
\text { értékelése }\end{array}$ & & & & & \\
\hline $\begin{array}{l}\text { 6. Olvasott szöveg- } \\
\text { értés mérése }\end{array}$ & & & & & \\
\hline $\begin{array}{l}\text { 7. Íráskészség érté- } \\
\text { kelése }\end{array}$ & & & & & \\
\hline $\begin{array}{l}\text { 8. A négy nyelvi } \\
\text { készség integrált } \\
\text { mérése }\end{array}$ & & & & & \\
\hline $\begin{array}{l}\text { 9. Tanulói önérté- } \\
\text { kelés használata }\end{array}$ & & & & & \\
\hline $\begin{array}{l}\text { 10. Tanulótárs általi } \\
\text { értékelés hasz- } \\
\text { nálata }\end{array}$ & & & & & \\
\hline $\begin{array}{l}\text { 11. Tanulói portfólió } \\
\text { használata }\end{array}$ & & & & & \\
\hline $\begin{array}{l}\text { 12. Speciális tanulá- } \\
\text { si nehézséggel } \\
\text { rendelkező tanu- } \\
\text { lók értékelése } \\
\text { (pl. diszlexia) }\end{array}$ & & & & & \\
\hline $\begin{array}{l}\text { 13. A tanulók felké- } \\
\text { szítése külső } \\
\text { vizsgákra (pl. } \\
\text { érettségi, nem- }\end{array}$ & & & & & \\
\hline
\end{tabular}


Pedagógusképzés • 18(46), 2019/3-4.

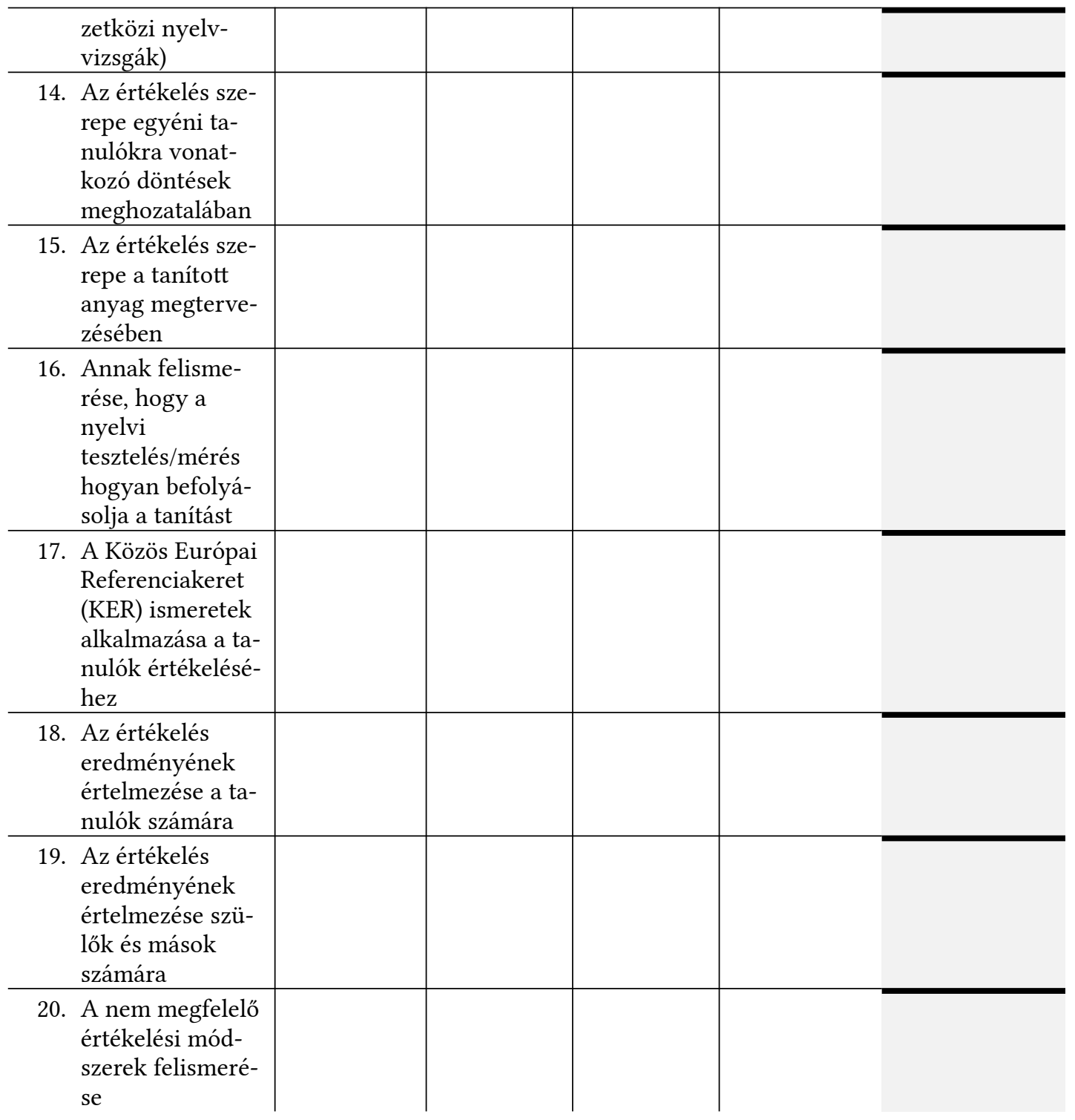

